\title{
THE MISMATCHES BETWEEN MINORITY LANGUAGE PRACTICES AND NATIONAL LANGUAGE POLICY IN MALAYSIA: A LINGUISTIC LANDSCAPE APPROACH
}

\section{Wang Xiaomei ${ }^{{ }^{*}}$ and Xu Daming ${ }^{2}$}

${ }^{1}$ Department of Chinese Studies, Xiamen University Malaysia, Selangor, MALAYSIA

${ }^{2}$ Department of Chinese Language and Literature, Faculty of Arts and Humanities, University of Macau, Macau, CHINA

*Corresponding author: xmwang@xmu.edu.my

Published online: 27 April 2018

To cite this article: Wang, X. and D. Xu. 2018. The mismatches between minority language practices and national language policy in Malaysia: A linguistic landscape approach. Kajian Malaysia 36(1): 105-125. https://doi.org/10.21315/km2018.36.1.5

To link to this article: https://doi.org/10.21315/km2018.36.1.5

\begin{abstract}
The paper takes a linguistic landscape (LL) approach to the language use of two minority communities in Malaysia. A total of 689 digital photos of public signs were collected from two main streets in Chinatown and Little India, Kuala Lumpur and were analysed quantitatively with the aid of FileMaker 10.0. For each of the signs in the database, it is determined whether it is a monolingual or a multilingual sign, what language(s) is/are used in the sign, and which of the languages used is the dominant one in the case of a multilingual sign. On basis of the above characteristics of the signs, the visibility of the different languages in the linguistic landscape was analysed. The analysis shows the following ranking order of the visibility: Chinese, English and Malay in Chinatown; and English, Malay and Tamil in Little India. These findings show that the linguistic practices of the two ethnic minorities deviated from the language policy of the state, which is to promote Malay, the national language. The mismatches between the state policy and the minority community practice are explained both by the non-use value of identity expression and the use value of communication of LL and by the political and economic motivations of language policy.
\end{abstract}

Keywords: linguistic landscape, Chinese, Tamil, Malay, language policy 


\section{INTRODUCTION}

Scholars in the area of linguistic landscape (LL) have analysed language use in public space in many different perspectives, including language planning (Shohamy, 2015), language and identity (Wang and van de Velde, 2015), and societal multilingualism (Backhaus, 2007). Meanwhile, minority language groups in multilingual societies have received much attention (Gorter, Marten and Mensel, 2012; Cenoz and Gorter, 2006). The studies found that LL is not only a way to show the realities of language use, but also a window to see the tension between practices, beliefs and managements in language policy, which is especially so in a multilingual society. Following the trend, the present study focuses on the language use of two minority groups, the Chinese and the Indians in Malaysia. The language use of Chinese and Indian communities in Malaysia has been studied in the perspective of language and identity, but not yet placed in the perspective of language planning. Therefore, in the present study the interactions between state language policy and community practice will be investigated and discussed with the LL data from the specific situations in Malaysia.

As found by previous studies, language policy is not always implemented in practice and there is covert and implicit language planning hidden in language practices (Coady and Laoire, 2002; Shohamy, 2006; du Plessis, 2012; among others). According to Shohamy (2006: 110-133), LL is one of the mechanisms or policy devices where covert and implicit language planning can be revealed. LL as a policy device "determines not only the ideological message, but also the choice of languages" (Shohamy, 2006: 123). Accordingly, du Plessis (2012: 265-266) identified two schools of thoughts with the issue: (1) "language policy intervention in the LL as a positive outcome of language planning", (2) "the casual relation (between language policy and LL) is not necessarily uni-directional and one dimensional". Among the studies on the relation between language policy and LL, especially those whose research context is multilingual European countries, most seem to support a positive finding that "the LL seems to reflect the general sociolinguistic situation as well as the intensity of language policies for the minority language" (Cenoz and Gorter, 2006: 74). Therefore, it would be interesting to find out whether the LL of Chinese and Indian communities in Malaysia, in a multilingual context in Asia, would also be a case of the positive finding as in the European context.

Apart from the issue on LL as outcomes of language policy, studies of LL also raised the issue of economic value of LL. Cenoz and Gorter (2006) studied the use of two minority languages, Basque in Spain and Frisian in the Netherlands respectively. Their study pinpointed the economic and commercial values of English appearing in the LL of minority communities (Cenoz and Gorter, 2006; 2009). Similarly, in the study on the LL in Kuala Lumpur, English is also 
analysed for its advertising effect and symbolic value (Manan et al., 2015). With the economic value of English highlighted in many studies, the literature shows a relative lack of attention towards the economic value of minority languages. Following the study of language economics (Grin, 2003; Grin, Sfreddo and Vaillancourt, 2010), the economic value of minority languages was discussed in the context of language planning in China (Xu and Li, 2010: 33). In contrast, the LL studies tended to focus on the role of minority languages as the symbol of ethnic identity and no exploration was made to gauge the economic value of minority languages in LL. Bearing this research gap in mind, the present study will also include the discussion of the economic value of minority languages in LL and their relevance in language policy and language planning. The main research questions of the study are as follows: (1) What are the characteristics of the LL in the locations of Chinese and Indian communities in Malaysia? (2) What effects of overt and covert language policies are shown by the LL in the two minority communities? and (3) Is there any economic value in the minority languages in the LL and what is the implication for language policy? The remainder of the article includes a sketch on the language planning towards minority languages in Malaysia and a report on an investigation on the LL in Chinatown and Little India in Kuala Lumpur, as representations of language practices of Chinese and Indian communities in Malaysia, and a discussion on the effects of national language policies on the practices of minority communities, referring to the analytical results of the LL data.

\section{LANGUAGE PLANNING TOWARDS MINORITY LANGUAGES IN MALAYSIA}

Malaysia is a multiethnic and multilingual country where more than 80 languages are spoken by the different ethnic populations of the country on top of Malay, the designated national language and the language of the majority population (Asmah, 2004). The Chinese and Indians are two major minority groups in Malaysia representing $24.6 \%$ and $7.3 \%$ of the total population of the country respectively (Department of Statistics Malaysia, 2010). Accordingly, Chinese and Tamil are two important languages with large amount of speakers. The rich linguistic resources are one of the major characteristics of this Southeast Asian nation. However, after obtaining its independence from the British colonial rule in 1957, Malaysia has adopted a monolingual-oriented national language policy, with a view to foster national identity and solidarity. There are two legal documents which address language issues in Malaysia. The first one is the Federal Constitution of Malaysia in 1957 which defines the status of Malay as the national language of Malaysia. The second one is the Language Act in 1967 which proclaims that Malay is the 
national language and sole official language in Malaysia. However, the minority languages, including Chinese and Tamil, are not accorded any formal status in the documents. In fact, they are referred to in the Federal Constitution in the following manner:

1. No person shall be prohibited or prevented from using (otherwise than for official purposes), or from teaching or learning, any other language; and

2. Nothing in this Clause shall prejudice the right of the Federal Government or of any State Government to preserve and sustain the use and study of the language of any other community in the Federation (Article 152, Federal Constitution 2010; reprint).

Therefore, most language planning activities about Chinese and Tamil languages are through education. For instance, in national schools, Chinese and Tamil may be taught as an elective subject at the request of 15 pupils. In fact, the Chinese community, which represents near a quarter of the total population, made their appeal in the 1950s that Chinese language should be one of the official languages in Malaysia (Kua, 1985). However, the government subsequently declined the appeal. In 1969, the Malaysian Chinese Association (MCA) made the request that both Chinese and Tamil should be treated as official languages (Ye, 2002: 30). Again the appeal was not accepted. Although the appeals were not successful, the voices of minority groups were heard. These appeals for official status are seen as a way to safeguard education in Chinese and Tamil languages. If official status is obtained, the mother-tongue education for the minority group can be better protected.

Although the national constitution does not prohibit the use, teaching or learning of languages other than Malay, the minority languages ${ }^{1}$ are undergoing decline and language shift due to lack of official support (cf. Coluzzi, Nora Riget and Wang, 2013; Ting and Ling, 2013; Wang and Chong, 2011, among others). The linguistic diversity in Malaysia seems to be threatened as what has taken place in many parts of the world. Nevertheless, the minority groups such as Chinese and Indians have put great efforts in preserving their languages through education, daily usage, public signage and other means (Mohan and Wang, 2011).

Chinese and Tamil schools have been playing important roles in maintaining Chinese and Tamil languages (Mohan and Wang, 2011). Chinese and Tamil primary schools use Mandarin and Tamil as their main medium of instruction respectively. In 2013, there were 1,293 Chinese primary schools with a total student population of 564,510 and 523 Tamil primary schools with a total student population of $92,934 .^{2}$ Although other minority languages such as Semai, Iban and Kadazandusun are taught as school subjects in certain schools, ${ }^{3}$ many 
other indigenous languages are not included in school syllabus. Most children of these indigenous populations enter national schools and learn knowledge through Malay, the national language, which may be one of the factors leading to language shift (Coluzzi, Nora Riget and Wang, 2013; Ting and Ling, 2013).

As these minority languages have no official status, there are practically no official efforts in corpus planning towards these languages. As an agency for language planning, Dewan Bahasa dan Pustaka (Institute of Language and Literature) was set up by the government to be in charge of corpus planning of the Malay language. There are no similar agencies set up for the minority languages. As Chinese and Tamil schools were made parts of the national education system, the standardisation of Chinese and Tamil languages became the task of the Ministry of Education. For instance, the decision to introduce simplified Chinese characters and Hanyu Pinyin into Chinese schools in 1982 was made by the Ministry of Education with the launch of the new primary school curriculum (KBSR, Kurikulum Baru Sekolah Rendah) (Wang, 2014). However, the usage of minority languages outside schools lacks official planning. Despite the lack of support from the government, the Chinese community founded the Chinese Standardization Committee in 1997 and it was restructured and renamed as the Chinese Language Standardization Council of Malaysia in 2004. The main objective of the council was to promote standard Mandarin in Malaysia. The standardisation of the lexicon, such as the Chinese translation of place names and personal names of non-Chinese origin, is among its achievements. Recently, they introduced the Putonghua Proficiency Test from China with the aim of promoting standard Putonghua in Malaysia. In East Malaysia, there are some community-based agencies that promote the use of indigenous languages such as Dayak Bidayuh National Association (DBNA) for Bidayuh and the Tun Jugah Foundation for Iban in Sarawak, East Malaysia. These are non-profit associations with an aim to preserve and revitalise indigenous cultures and languages and published word lists of indigenous languages and managed pre-school project of language learning.

Finally, it is necessary to find out the relevant policies specifically applicable to LL. For the language use on signage or advertisement, the Kuala Lumpur City Hall and Petaling Jaya Municipal Council enacted the following policies: (1) The national language shall be used for all advertisements whether by itself or together with any other language; (2) If the national language is used with any other language in an advertisement, the words in the national language shall be: (a) $30 \%$ larger than the other language in measurement; (b) prominently displayed; and (c) grammatically correct (Manan et al., 2015: 5).

To summarise, the above sketch should give the information on the general sociolinguistic situation, the national language policy and status of minority languages in Malaysia. Although the national policy does not give sufficient support to the minority languages, the minority communities have managed in 
maintaining the languages to a great extent by education and daily use. Meanwhile, we see the policies of two Municipalities in regard to language use in signage and advertising, which conforms with the national language policy and also with a number of constraints on the use of other languages.

\section{THE STUDY OF LINGUISTIC LANDSCAPE}

The LL studies tend to focus on urban settings in capital cities or cosmopolitan centers where the presence of two or more languages in LL seems to be a norm (Backhaus, 2007). For instance, Manan et al. (2015) studied five neighbourhoods in Kuala Lumpur, the capital city of Malaysia, and described the use of Malay, English and minority languages (Chinese and Tamil) and analysed it from sociopolitical, economic and ethnolinguistic dimensions respectively. Accordingly, the present study on the relationship between language practice and national language policy also used the data of LL of two areas in Kuala Lumpur, the capital of Malaysia and one of the most prominent cosmopolitan cities in Southeast Asia. Chinatown and Little India in KL are notably the areas with the most presence of the Chinese and the Indian community respectively and they are thus chosen as the research sites for the present study.

\section{Research Sites}

Both Chinatown and Little India have hundreds of years of history as the residential area for the respective ethnic community but they are now well noted for being commercial areas catering both to the local community and visitors. With both areas becoming tourist hotspots in KL, the ethnic presence was further enhanced, not only by the local population but also by visitors of Chinese and Indian origin from other parts of Malaysia and other countries.

The present Chinatown consists of Jalan Petaling, Jalan Sultan and the surrounding areas. The Petaling Street is the core of Kuala Lumpur's Chinatown. In the Chinese community, Petaling Street is called Cíchăng Jiē in Mandarin or Chee Cheong Kai in Cantonese. Chee Cheong Kai is literally translated to mean "tapioca factory" street. Two large Chinese arches were placed on either end of the street to welcome visitors. The green roof cover over the entire street is now dubbed the "Green Dragon". The street had been totally transformed into a pedestrian shopping mall and is designated as a cultural heritage site (Bristow and Lee, 1994). Its all-day parade of stalls sell a vast variety of goods and also offers a large selection of local Chinese cuisine. Besides tourists, the locals, especially the Chinese, still throng to Petaling Street in order to shop for their Chinese New Year and other Chinese festival necessities. 
Little India, also known as Brickfields, dating back to the time of British colonial rule when the area specialised in producing bricks for construction works. It is located just south of city centre, adjacent to Kampung Attap to the north, Bangsar to the west, Taman Seputeh to the east and Mid-Valley Mega mall to the south. Brickfields is manifested through many religious buildings. Some of them are over 100 years old. Sri Kanda Samy Temple, Sri Vivekananda Ashram, Buddhist Maha Vihara are testimony of its history. A number of religious institutions found in this area form the basis for the concentration of the Indian population. Brickfields is not only a place of choice for the local Indian population but also for a large number of Indian expatriates who dwell in high-rise condominiums and apartments along Jalan Sultan Abdul Samad. Brickfields has many shops that are owned by Indian businessmen. Its main road, Jalan Tun Sambanthan, formerly known as Brickfields Road, is lined from one end to the other with shops selling Indian groceries, traditional food, sweets and snacks, textiles, ornaments, garlands, VCDs and anything that an Indian family needs. Brickfields "Little India" has turned into one of Kuala Lumpur's tourist hot spots not only because of the wares found there but also for its proximity to KL Central station.

\section{Data Collection}

The fieldwork was carried out in August 2012. A total of 689 signs from two main streets, the Petaling Street in Chinatown and the Tun Sambanthan Road in Little India were photographed using digital cameras. A "sign" is defined as "any piece of written text within a spatially definable frame" (Backhaus 2007: 66). With this definition, signs in this study included the visible signage from advertisements or flyers pasted on pillars and walls to huge posters or banners on perimeter fences or buildings. Signs that are invisible to the public from outside were excluded. Figure 1 shows a Sample taken in Little India, which is a multilingual sign containing three languages, English, Malay and Chinese.

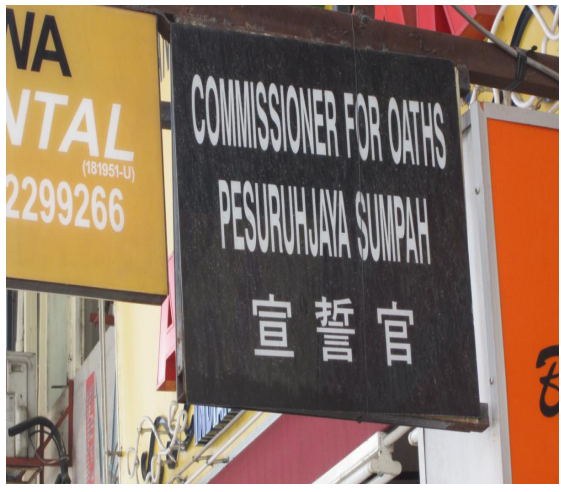

Figure 1: A multilingual sign in Little India. 


\section{Data Analysis}

The 689 photos were processed with FileMaker 10.0. The following parameters were set for data analysis: the number of languages used in the sign, the text characteristics such as colour of script, size of script, the type of the sign, the languages used in the sign, and the dominant language as appears in the sign. Among these parameters, the languages used and the dominant language in the sign are two important indicators in the measurement of visibility of a language in LL. To determine the dominant language in a multilingual sign, the size of script and its position in the sign are two main criteria (Scollon and Scollon, 2003). The language with bigger size and appearing in more prominent position in the sign is taken as the dominant language. The concept of "dominant language" is used as an indicator of code preference (Backhaus, 2007). Figure 2 illustrates the dominance of Malay in a multilingual sign as its size is bigger than English and Tamil and it is written at the top of the sign.

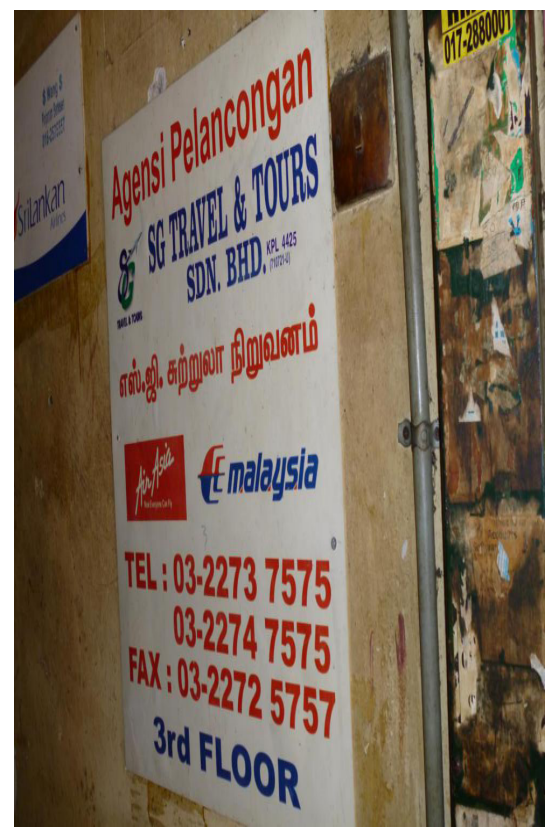

Figure 2: Malay as the dominant language in a multilingual sign.

With the number of languages used in a sign determined, all entries are categorised as monolingual signs or multilingual signs. A multilingual sign is defined as a sign containing at least two languages. In some studies, different scripts of one language is also regarded as multilingual (Backhaus, 2007). Similarly, Chinese can be represented in characters or Roman alphabet, especially 
for the name of shops. However, in this study, if the Chinese shop name in Roman alphabet is embedded in the text of English or Malay, it is regarded as English or Malay.

The visibility of a language in LL in a multilingual context is defined by three parameters: (1) the frequency of occurrence of the language in all signs; (2) the number of multilingual signs in which the language is used as the dominant language; and (3) the number of monolingual signs of the language.

\section{RESULTS OF INVESTIGATION}

\section{The Multilingual Nature of the LL}

In both Chinatown and Little India, most public signs are multilingual ${ }^{4}$ (see Table 1). Among the 388 signs in Chinatown, $56.7 \%$ of them contain more than one language. In Little India, $69.77 \%$ of the 301 signs are multilingual. More specifically, bilingual signs are more common than trilingual signs whereas there are signs with four languages but they are very small in number. Among the bilingual signs in Chinatown (see Table 2), the combination of Chinese and English (46.53\%) is most frequently observed followed by Chinese-Malay signs (29.17\%). In Little India, Tamil-English signs are the most seen bilingual signs (42.59\%) followed by English-Malay signs (29.63\%). The bilingual signs containing Chinese language also appear in Little India (15.74\%). However, bilingual signs containing Tamil language are not found in Chinatown. In Chinatown, almost all of the trilingual signs are Chinese-English-Malay signs (97.18\%). However, the trilingual signs in Little India follow different patterns: $60 \%$ of them contain Tamil, English and Malay and $31.11 \%$ of them are Malay-English-Chinese signs.

Table 1: Monolingual and multilingual signs in Chinatown and Little India

\begin{tabular}{lccc}
\hline Sign & Chinatown & Little India & Total \\
\hline Monolingual & $168(43.30 \%)$ & $91(30.23 \%)$ & $259(37.59 \%)$ \\
Bilingual & $144(37.11 \%)$ & $108(35.88 \%)$ & $252(36.57 \%)$ \\
Trilingual & $71(18.30 \%)$ & $90(29.90 \%)$ & $161(23.37 \%)$ \\
Others & $5(1.29 \%)$ & $12(3.99 \%)$ & $17(2.47 \%)$ \\
\hline Total & $388(100 \%)$ & $301(100 \%)$ & $689(100 \%)$ \\
\hline
\end{tabular}


Table 2: Bilingual signs in Chinatown and Little India

\begin{tabular}{lcclcc}
\hline Chinatown & Frequency & $\mathbf{\%}$ & Little India & Frequency & $\mathbf{\%}$ \\
\hline Chinese + English & 67 & 46.53 & Tamil + English & 46 & 42.59 \\
Chinese + Malay & 42 & 29.17 & English + Malay & 32 & 29.63 \\
English + Malay & 32 & 22.22 & Tamil + Malay & 11 & 10.19 \\
Others & 2.08 & English + Chinese & 10 & 9.26 \\
& & & Malay + Chinese & 7 & 6.48 \\
& & & Others & 2 & 1.85 \\
\hline \multicolumn{1}{c}{ Total } & 144 & 100 & Total & 108 & 100 \\
\hline
\end{tabular}

The languages in the LL include Chinese, Tamil, Malay and English. In total, $70.88 \%$ of the signs in Chinatown use Chinese language and $44.19 \%$ of the signs in Little India contain Tamil language. English appears on $57.48 \%$ of the signs in Chinatown and $86.05 \%$ in Little India. The proportion of signs containing Malay is $45.10 \%$ in Chinatown and $54.82 \%$ in Little India. This indicates that multilingualism is a salient feature of the LL in both Chinatown and Little India. Figure 3 illustrates how different languages are used in a single sign. The four languages (Malay, English, Chinese and Tamil) in this sign appear in different colour and size. Malay appears at the top in blue and in the biggest size followed by English in black. Below is Chinese in red and Tamil which appears at the bottom of the sign and in green.

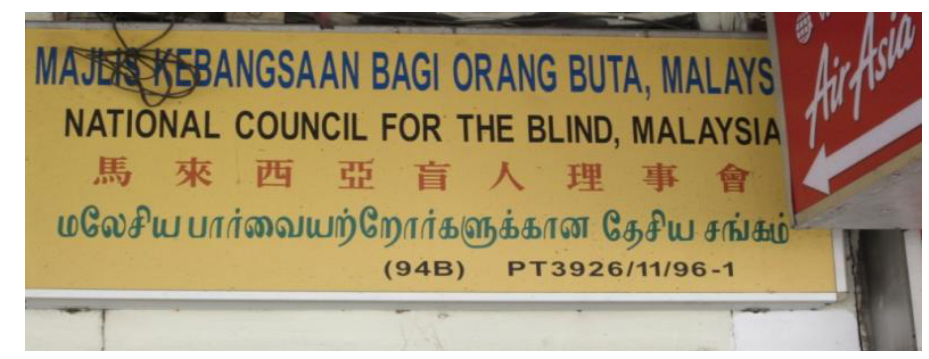

Figure 3: A multilingual sign in Little India.

The proportion of multilingual signs is higher than that reported in the study of minority areas in Europe (Cenoz and Gorter, 2006). In the study of the two minority language areas in Spain and the Netherlands, the multilingual signs account for $54 \%$ and $36 \%$ of the totals respectively, which are lower than what we found in Chinatown and Little India. Among multilingual signs, the most visible combination is English and an ethnic language, 46.53\% for English-Chinese signs in Chinatown and $42.59 \%$ for English-Tamil signs in Little India (see Table 2). 


\section{High Degree of Visibility of Minority Languages}

There are three parameters for the visibility of an ethnic language in LL. The first one is the total frequency of the ethnic languages in the signs. Based on the collected data in Chinatown and Little India, Chinese (70.88\%) and Tamil (44.19\%) are both used extensively (see Table 3). The occurrence of Chinese is much higher than that of Tamil, which is due to the fact that there is a unified script for various Chinese dialects. Moreover, Tamil is only one of the languages or scripts used by the Indian community. The second parameter for the visibility of a language is the proportion of the signs where as it is the dominant language in total number of the multilingual signs. If it appears either in a bigger size than other languages or in the top position of a sign, it is taken as the dominant language of the sign (Scollon and Scollon, 2003). In Chinatown, Chinese is the dominant language in $42.53 \%$ of the multilingual signs while Tamil is dominant in $19.6 \%$ of the multilingual signs in Little India (Table 3). Again, the frequency of Chinese as the dominant language is higher than that of Tamil. Besides the reason given above, the low frequency of Tamil is associated with the extensive use of English in Little India, which will be discussed in the following section. The third parameter for the visibility of ethnic languages is their frequency of occurrence in monolingual signs (see Figure 4). Monolingual signs use only one language to convey messages and they target only those who are literate in this language. In the current study, $91(23.45 \%)$ Chinese monolingual signs are found in Chinatown while only $4(1.33 \%)$ Tamil monolingual signs are noted in Little India (Table 3). Reasons leading to such differences between Chinatown and Little India are to be given in the following section.

Table 3: The use of ethnic languages in Chinatown and Little India

\begin{tabular}{lcc}
\hline & $\begin{array}{c}\text { Chinese language in } \\
\text { Chinatown }\end{array}$ & $\begin{array}{c}\text { Tamil language in Little } \\
\text { India }\end{array}$ \\
\hline As the dominant language & $165(42.53 \%)$ & $59(19.60 \%)$ \\
In monolingual sign & $91(23.45 \%)$ & $4(1.33 \%)$ \\
The frequency of ethnic languages & $275(70.88 \%)$ & $133(44.19 \%)$ \\
The total number of signs & $388(100 \%)$ & $301(100 \%)$ \\
\hline
\end{tabular}




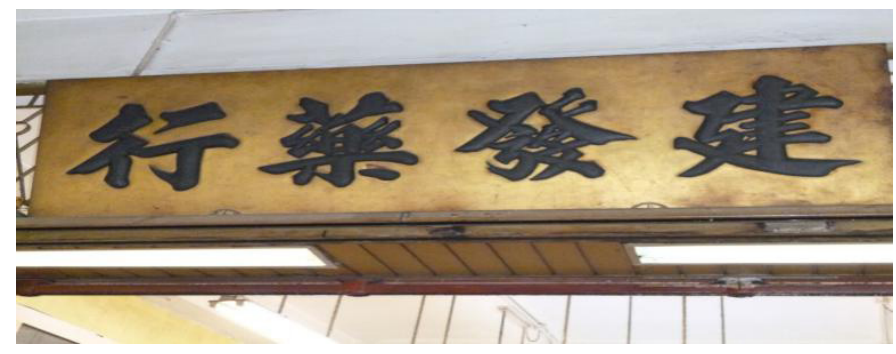

Figure 4: A monolingual sign in Chinatown.

\section{The Non-dominant Use of Malay}

The frequency of the use of Malay in public signs is $45.1 \%$ in Chinatown and $54.82 \%$ in Little India. The figure is even lower for Malay as the dominant language in a multilingual sign, which is $23.45 \%$ in Chinatown and $27.24 \%$ in Little India. Moreover, the Malay language seldom appears in monolingual signs. In total, there are only 25 (6.44\%) Malay monolingual signs in Chinatown and 16 (5.32\%) such signs in Little India. The use of Malay is not as prominent as English and ethnic languages in both communities. This seems not to follow the regulation by the Kuala Lumpur City Hall (Dewan Bandaraya Kuala Lumpur, DBKL) and Petaling Jaya Municipal Council, which states that Malay should appear prominently in a sign board. These figures show that the national language is not as dominant as other languages in public space and the language use in these two minority communities does not conform to the national language policy that emphasises the prominent status of Malay.

\section{The Dominance of English in Public Space}

In the LL in Chinatown and Little India, the total frequency of the use of English in public signs is $57.48 \%$ and $86.05 \%$, respectively, which is much higher than the occurrence of Malay in these two areas. As to the use of English as the dominant language in multilingual signs, the proportion is $32.73 \%$ in Chinatown and $49.5 \%$ in Little India. Figure 5 is a monolingual English sign in Chinatown, whose owner is a bank. 


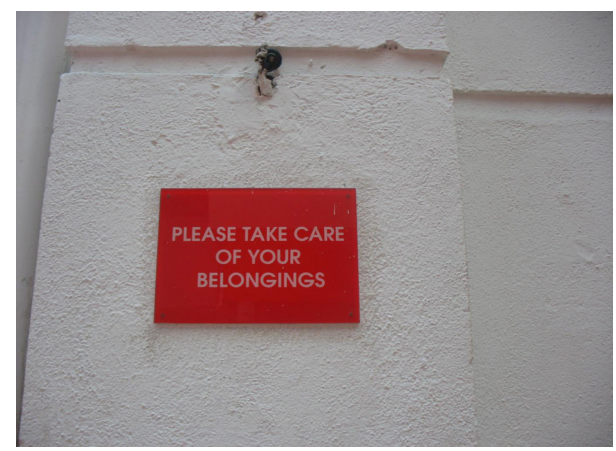

Figure 5: An English-monolingual sign in Chinatown.

\section{Summary}

The LL data reveal the multilingual mode of language use in Chinatown and Little India. The majority of public signs contain more than two languages. Although the order of preference in language choice is slightly different, the general pattern is similar in the range of the languages used. The ethnic languages, national language and international language are commonly used in public signs.

In Chinatown, the most used languages are Chinese (70.88\%), English (57.48\%), and Malay (45.10\%) in descending order. In Little India, English is mostly used (86.05\%), followed by Malay (54.82\%), and Tamil (44.19\%). Chinese is most visible in Chinatown while English is most visible in Little India.

\section{DISCUSSION}

The above findings reveal the actual language use in two minority communities. As shown by the findings, the practice of the two minority communities does not seem to conform with the national language policy. There are several mismatches between the actual language practices and official language policies, which is discussed below.

\section{The Mismatches between Language Practice and Language Policy}

\section{Monolingualism vs. Multilingualism}

Different from the monolingualism policies advocated by the government, a multilingual trend of language use is found in both minority communities. As 
reported in the previous section, multilingual signage is more common than monolingual signs in both Chinatown and Little India. The mismatch between the written language policy and actual language use reflects the tension between linguistic needs of minority communities and national linguistic ideology. The minority groups embrace multilingualism while the government promotes monolingualism.

Chinese and Indians make their languages visible in public space, which is a way to maintain their languages and express their identity (Manan et al., 2015; Wang et al., forthcoming). Both languages, in addition to market value, are attached with non-market value, which is "knowing language $\mathrm{L}_{\mathrm{x}}$ gives access to the associated cultural sphere, facilitates social contact with members of the $\mathrm{L}_{\mathrm{X}}{ }^{-}$ speaking community, etc" (Grin, 2003: 36). In the Malaysian context, speaking Tamil among Tamilians, and similarly, speaking Mandarin or Cantonese among Chinese will facilitate the socialisation of the people of the community. Even when they shift to English, they tend to speak a variety of Malaysian English with Tamil (or Chinese) accent to accommodate the interlocutors (Pillai, 2006).

The extensive use of minority languages in Chinatown and Little India shows the vitality of Chinese and Tamil in Malaysia. Although languages other than Malay are not obligatory in public signs, Chinese and Indians tend to display their ethnic languages in public space. In addition to the identity factor, the economic consideration has played an important role in the choice of codes in public space.

\section{The Use of Malay and English}

In many cases, the display of Malay on signs serve the symbolic function as opposed to the informational function (Landry and Bourhis, 1997), showing its status as the national language. Manan et al. (2015) also pointed out that the use of Malay on signs is out of sociopolitical consideration. In the Malaysian context, the presence of Malay on signs may facilitate the integration of minorities and avoid conflict, which is of indirect use value (Cenoz and Gorter, 2009).

The use of English seems to be prominent in both communities. A similar finding is reported by Manan et al. (2015) in their study on LL of five areas in Kuala Lumpur. Their findings show that English is the most prominent language (28\%) in Kuala Lumpur followed by Malay (19\%) based on 858 samples (Manan et al., 2015: 11). The high degree of visibility of English in public space has certainly some practical considerations. On the one hand, it indicates that English is still an important language in the commercial domain in Malaysia despite its non-official status. On the other hand, as English has become an international language, there is added value in using English on signs. As to the difference between Chinatown and Little India in terms of the occurrence of English, the importance of language to identity may account for it in addition to the factor of higher degree of heterogeneity 
within the Indian community. As pointed out by Pillai (2006: 72), the use of and shift to English by Malaysian Indians do not lead to the loss of their Indian identity. In contrast, the Chinese language is regarded as the core of Chinese identity. As a result, the maintenance of Chinese language, to some extent, is better than that of Tamil while the shift to English by the Indians is more prone to taking place.

English is associated with modernity and globalisation by some Malaysians (Coluzzi, 2015). In this sense, English has its indirect use value which helps to "give an image of a modern, cosmopolitan and multicultural city" (Cenoz and Gorter, 2009: 65). Proficiency in English has become one of the requirements in the job market in Kuala Lumpur and other cosmopolitan cities in Malaysia. Moreover, English has been a lingua franca across ethnic groups in the country. Therefore, the instrumental value of English is relatively high in comparison with other languages. As pointed out by Asmah (2004), English is still actively used in commercial, business and other private domains in Malaysia, which leads to its significance in public space. Particularly, Chinatown and Little India are both ethnic communities and tourism hot spots where English definitely is to attract both local and international customers. The customers receive information through English as used on the signs. Therefore, English has direct use value in the Malaysian context. As summarised by Cenoz and Gorter, "the omnipresence of English in LLs is one of the most obvious markers of the process of globalization" (2009: 57).

\section{The Differences between the Two Communities}

The Indian community consists of linguistic subgroups speaking Tamil, Telugu, Malayalam, Kannada, Hindi, Punjabi and a number of other Indian languages. As Tamil is not used as the lingua franca across these subgroups, there is no direct association between Tamil and the Indian identity. Therefore, the presence of Tamil on public signs is not as frequent as that of Chinese in Chinatown. The second factor lies in the lower market value of the Tamil language. According to Grin, "speaking language $\mathrm{L}_{\mathrm{X}}$ makes it easier to sell goods to the $\mathrm{L}_{\mathrm{X}}-$ speaking public and thereby gives rise to higher profits, or that an $\mathrm{L}_{\mathrm{X}}$-speaking employee earns more, all other things being equal, because he knows language $\mathrm{L}_{\mathrm{X}}$ : in this case, $\mathrm{L}_{\mathrm{X}}$ has market value" (2003: 36). In Malaysia, English is the most frequently used language in business and commercial sector followed by the Chinese language. Non-Tamilian Malaysians have little motivation to learn Tamil and there is no such program as teaching Tamil as a second language offered in local universities. As a result, Tamil lost its importance and visibility in public space. In contrast, the Chinese language is regarded as the core component of Chinese identity (Tan, 2000). Therefore, Chinese Malaysians tend to display their language on public signs. Even in Little India, 20.93\% of the signs contain Chinese, which shows the importance of the Chinese language in the commercial sector. In other words, it 
has a high market value in the Malaysian context. In fact, it is not uncommon to find Indians or Malays speaking Chinese language in Malaysia or sending their children to Chinese schools where Mandarin is the medium of instruction. ${ }^{5}$

\section{The Economic Values of LL}

Cenoz and Gorter pointed out, "the LL is in many cases linked to an economic value as in the case of commercial advertising" (2009: 64). They adopted the concepts from environmental economics to analyse the value of LL, which include use values and non-use values. Cenoz and Gorter further differentiated direct use values from indirect use values. The direct use values correspond to the informational function of LL proposed by Landry and Bourhis (1997), such as understanding the meaning of the signs or practicing the languages citizens know (Cenoz and Gorter, 2009: 65). The indirect use values refer to indirect use of linguistic diversity, including costs avoided. With indirect use values, there are "more possibilities to attract tourism and to work towards integration of different minorities and to avoid conflict" (Cenoz and Gorter, 2009: 65). For non-use values, Cenoz and Gorter (2009) identified two categories, bequest value and existence value. The bequest value of LL is actually related to language maintenance of minority languages. "If somebody's language or many languages are included in language signs, they are less likely to be lost" (Cenoz and Gorter, 2009: 66). The existence value reflects the situation that speakers of different languages enjoy the existence of these languages in LL because they identify with them but do not necessarily understand the languages. Cenoz and Gorter's framework for the analysis of the economic perspective of LL is of explanatory strength. Therefore, it has been adopted in the current study to explain the mismatches between linguistic reality and stated language policy.

It is observed that Chinese appears more in Chinatown than Tamil in Little India. The heterogeneity of the Indian community is one of the reasons leading to such a difference. Apart from it, the internationalisation or globalisation of Chinese language is the other factor contributing to its prominence in Malaysia. By displaying Chinese characters on signs, the shop owners may attract international tourists as well.

In recent years, the economic value of language use has been studied (Cenoz and Gorter, 2009; Grin, 1990; 2003; Grin, Sfreddo and Vaillancourt, 2010; $\mathrm{Xu}$ and Li, 2010; among others). Following Cenoz and Gorter (2009), the present study also examines the economic value of LL. Although the economic value of minority languages is discussed (Xu and Li, 2010; Xu, 2015), few empirical studies have been conducted in such perspective. In particular, among the LL studies, it is English as an international language that is shown to have the added value in the economic sense (Cenoz and Gorter, 2009) whereas the languages of ethnic 
minorities mostly show their symbolic value of identity expression. Therefore, it would be worthwhile to conduct a study of LL of a minority community to examine the economic value of minority languages on top of the well-recognised values of national and international languages.

The economic value of a public sign is enhanced with a multilingual feature. As a matter of fact, language use in public signs is actually a type of language service ( $\mathrm{Li}, 2010)$, provided to its potential users by supplying adequate language resources and in meeting their linguistic needs. For instance, the MalayChinese-English trilingual signs in Chinatown contain three different languages to accommodate customers from different linguistic and ethnic backgrounds. Malay is mostly for ethnic Malays and Chinese for ethnic Chinese from local and abroad as well while English has a broader range of readers including local residents and tourists from all over the world. As such, a multilingual sign can serve its purposes in a single sign. In contrast, a monolingual sign can only perform one function. In this sense, multilingual signs are more economical compared to monolingual ones. In a similar vein, a barber's shop or restaurant in Little India may use Chinese characters in their signs as Chinese are their potential customers and Chinese scripts are regarded as a strategy to attract these customers. Therefore, language choice in public signs can create value from the economic point of view. In fact, the linguistic diversity itself has promoted the multicultural and harmonious image of Kuala Lumpur, which is an added value and existence value as defined by Cenoz and Gorter (2009). The popular slogan for Malaysian tourism advertisement, "Malaysia, truly Asia" is actually emphasises the cultural and linguistic diversity of the country. The existence of different languages and cultures on this land is indeed an asset and can create values.

\section{CONCLUSION}

In this article, we have examined how the Chinese and the Indians in Malaysia display different languages in their communities and then whether their linguistic practices are in line with the national language policies. The data of LL from these two minority communities indicate that: (1) multilingualism is preferred by minority groups as opposed to the monolingual policy by the government, (2) the national language Malay is not used as frequently as expected per the stated policy, and (3) both English and the minority languages are prominently used in both communities.

The findings suggest that language practices at the community level constitute covert language policies that may be opposed to the national language policy. The choices of languages in LL by the minority communities reflect the real needs of the community in their cultural as well as economic life. 
Cenoz and Gorter's (2009) proposal on economic value of LL is supported by our findings. The economic value (both use value and non-use value) of multilingual signs is significant in accounting for the prominence of English and minority languages in LL. Compared to previous research, this study has shown that the diversity of LL itself is of great value from the point of view of language economics.

The complexity of language practices in minority communities shows that multiple forces are in effect. The implications are that successful language policies need to cater to the complexity of language usage and political and economic motivations need to be balanced in language planning.

\section{ACKNOWLEDGEMENTS}

This article is supported by Beijing Advanced Innovation Center for Language Resources, Grant No.: KYR17001.

\section{NOTES}

1. Minority communities in this article refer to those ethnic groups in Malaysia whose population is less than the dominant ethnic group, the Malay community, such as the Chinese community and the Tamil community. Minority languages refer to the languages spoken by these minority communities such as Mandarin and Tamil. As most of time minority languages are associated with specific ethnic groups, the term ethnic language is also used interchangeably in this article.

2. http://www.djz.edu.my/resource/images/doc/DataAnalysis/2013\%20 AnnualReport-DataAnalysis\%206.pdf (accessed 26 February 2016).

3. http://www.moe.gov.my/en/pelajaran-rendah (accessed 26 February 2016).

4. Multilingualism in this paper refers to the use of more than one language in public space.

5. According to the statistics of the Ministry of Education Malaysia, $15.31 \%$ of the students in Chinese primary schools are non-Chinese origin in 2014. Please refer to the detailed report at the following website: http://www.orientaldaily.com. my/s/64088 (accessed 21 June 2017). 


\section{REFERENCES}

Asmah Haji Omar. 2004. The encyclopedia of Malaysia: Vol. 9 Languages and Literature. Singapore: Edition Didier Millet.

1982. Language and society in Malaysia. Kuala Lumpur: Dewan Bahasa dan Pustaka.

Attorney General's Chambers of Malaysia. 2010. Federal Constitution (reprint). http:// www.agc.gov.my/images/Personalisation/Buss/pdf/Federal\%20Consti\%20 (BI\%20text).pdf (4 September 2015).

Backhaus, P. 2007. Linguistic landscapes: A comparative study of urban multilingualism in Tokyo. Clevedon: Multilingual Matters.

Bristow, S. and E. Lee. 1994. Chinatown Kuala Lumpur. Kuala Lumpur: Tropical Press.

Cenoz, J. and D. Gorter. 2009. Language economy and linguistic landscape. In Linguistic landscape: Expanding the scenery, eds. E. Shohamy and D. Gorter, 55-69. New York and London: Routledge.

2006. Linguistic landscape and minority languages. International Journal of Multilingualism 3(1): 67-80. https://doi.org/10.1080/14790710608668386

Coady, M. and M. O. Laoire. 2002. Mismatches in language policy and practice in education: The case of Gaelscoileanna in the Republic of Ireland. Language Policy 1: 143-158. https://doi.org/10.1023/A:1016102201242

Coluzzi, P., P. Nora Riget and X. Wang. 2013. Language vitality among the Bidayuh of Sarawak (Eastern Malaysia). Oceanic Linguistics 52(2): 375-395. https://doi. org/10.1353/ol.2013.0019

Coluzzi, P. 2015. Economic phenomena and ideologies behind language shift. Language Problems and Language Planning 39(1): 70-83. https://doi.org/10.1075/ lplp.39.1.04col

Department of Statistics Malaysia. 2010. Population distribution and basic demographic characteristics 2010. http://www.statistics.gov.my/portal/download_Population/ files/census2010/Taburan_Penduduk_dan_Ciri-ciri_Asas_Demografi.pdf (accessed 9 June 2014).

$\mathrm{du}$ Plessis, T. 2012. The role of language policy in linguistic landscape changes in a rural area of the Free State Province of South Africa. Language Matters 43(2): 263282. https://doi.org/10.1080/10228195.2012.741098

Grin, F. 2003. Language planning and economics. Current Issues in Language Planning 4(1): 1-66. https://doi.org/10.1080/14664200308668048 1990. The economic approach to minority languages. Journal of Multilingual and Multicultural Development 11(1/2): 153-173.

Grin, F., C. Sfreddo and F. Vaillancourt. 2010. The economics of the multilingual workplace. Oxford: Routledge.

Gorter, D., H. F. Marten and L. V. Mensel. 2012. Minority languages in the linguistic landscape. London: Palgrave Macmillan. https://doi.org/10.1057/9780230360235

Han, H. 2013. Individual grassroots multilingualism in Africa town in Guangzhou: The role of states in globalization. International Multilingual Research Journal 7: 83-97. https://doi.org/10.1080/19313152.2013.746803 
Kua, K. S. 1985. Malaixiya huajiao fendoushi [Protean Saga: The Chinese Schools of Malaysia]. Kajiang: Dongjiaozong Higher Learning Centre.

Landry, R. and R. Y. Bourhis. 1997. Linguistic landscape and ethnolinguistic vitality: An empirical study. Journal of Language and Social Psychology 16(1): 23-49. https://doi.org/10.1177/0261927X970161002

Lee, K. H. and B. T. Chee. 2000. The Chinese in Malaysia. Kuala Lumpur: Oxford University Press.

Li, X. 2010. Studies on language service from the perspective of language resource and language issues. Journal of Yunnan Normal University 5: 16-21.

Manan Abdul Syed, M. K. David, F. P. Dumanig and Khan Naqeebullah. 2015. Politics, economics and identity: Mapping the linguistics landscape of Kuala Lumpur, Malaysia. International Journal of Multilingualism 12(1): 31-50. https://doi.org/ 10.1080/14790718.2014.905581

Mohan, L. S. and X. Wang. 2011. Ethnolinguistic vitality of minority communities in a multilingual society: A comparative study of the Chinese and Indians in Malaysia. Journal of Chinese Sociolinguistics 2: 11-29.

Pillai, S. 2006. Malaysian English as a first language. In Language choices and discourse of Malaysian families, ed. M. K. David, 61-75. Kuala Lumpur: Strategic Information \& Research Development Centre (SIRD).

Scollon, R. and W. Scollon. 2003. Discourses in place: Language in material world. London: Routledge. https://doi.org/10.4324/9780203422724

Shohamy, E. 2015. Linguistic landscape research as expanding language and language policy. Linguistic Landscape 1(1/2): 152-171. https://doi.org/10.1075/11.1.12.09sho 2006. Language policy: Hidden agendas and new approaches. London and New York: Routledge.

Signline. 2007. The value of signs for your business. Signline. 1: 1-8.

Spolsky, B. 2009. Language Management. New York: Cambridge University Press. https:// doi.org/10.1017/CBO9780511626470

Tan, C. B. 2000. Socio-cultural diversities and identities. In The Chinese in Malaysia, eds. K. H. Lee and B. T. Chee, 37-70. Kuala Lumpur: Oxford University Press.

Ting, S. H. and T. Y. Ling. 2013. Language use and sustainability status of indigenous languages in Sarawak, Malaysia. Journal of Multilingual and Multicultural Development 34(1): 77-93. https://doi.org/10.1080/01434632.2012.706301

$\mathrm{Xu}, \mathrm{D}$. 2015. The political and economic benefits of mother-tongue equality policy. In The contemporary language policy and language transmission in China, ed. L. Bao, 243-252. Tokyo: Sangensha Publishers.

$\mathrm{Xu}, \mathrm{D}$. and X. Li 2010. Protect linguistic resources and develop language economics. Journal of Beihua University 1: 32-36.

Wang, X., P. N. Riget, S. Shoniah and C. K. Yi. 2017. Constructing identities through linguistic landscape: A comparison between Chinatown and Little India in Kuala Lumpur. In Linguistic minorities: Their existence in larger communities, ed. Asmah Haji Omar, 120-142. Kuching: UNIMAS Press. 
Wang, X. 2014. Chinese education in Malaysia: Past and present. In Learning Chinese in diasporic communities: Many pathways to becoming Chinese, eds. CurdtChristiansen, Xiao Lan and Andy Hancock, 139-157. Amsterdam: John Benjamins Publishing Company.

Wang, X. and S. L. Chong. 2011. A hierarchical model for language maintenance and language shift: Focus on the Malaysian Chinese community. Journal of Multilingual and Multicultural Development 32(6): 577-591. https://doi.org/10.1 080/01434632.2011.617820

Wang, X. and H. van de Velde. 2015. Constructing identities through multilingualism and multiscriptualism: The linguistic landscape in Dutch and Belgian Chinatowns. Journal of Chinese Overseas 11(2): 119-145. https://doi.org/10.1163/1793254812341302

Ye, Y. X. 2002. Yuyan zhengce yu jiaoyu: Malaixiya yu Xinjiapo zhi bijiao [Language policy and education: Comparison between Malaysian and Singapore]. Taipei: Avanguard Publishing Company. 